\title{
JOURNAL.RU
}

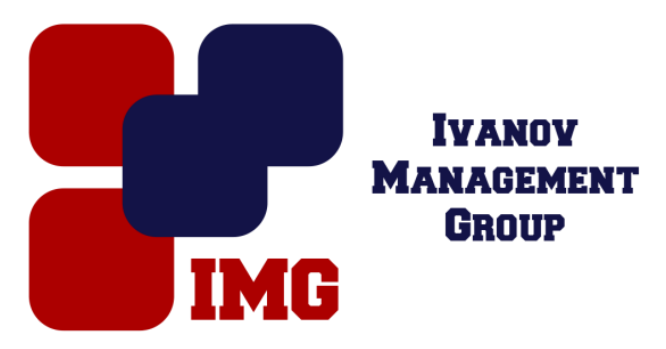

Акимбекова А.Ф., Курманбаева Д.А.

Казахский агротехнический университет имени С.Сейфуллина Астана, Республики Казахстан

doi: $10.18411 / \mathrm{lj}-31-07-2017-30$

idsp 000001:1j-31-07-2017-30

\section{Слепни (Diptera,Tabanidae) Северной части Казахстана}

\section{Аннотация}

Слепни-крупные представители кровососущих двукрылых насекомых многочисленны на территории в северных областях Казахстана. В ходе исследований стало достоверно установлено о 23 вида кровососущих двукрылых насекомых, относящийся родам: Tabanus,Chrysops, Haematopota, Hybomitra, Atylotys.Из кровососущих двукрылых насекомых доминируют слепни рода Tabanus,. Нами были обнаружены европейские, туркестанские, средиземноморские и монгольские фаунистические элементы слепней.

Ключевые слова: гнус; слепни; фауна; фенология;

Актуальность темы. Слепни семейство Tabanidae (Diptera) многочисленные и широко распространенные в природе насекомые, которых относят к микрохищникам или паразитом. Самки большинства видов кровососы и для человека и домашних животных они нередко представляют серьезную опастность, которая слагается из их массового паразитирования и способности переносить возбудителей многих инфекционных и инвазионных болезной.Слепни (Diptera, Tabanidae),будучи активными кровососами, за исключением некоторых видов, являются одним из основных компонентов гнуса. Они распространены в большинстве районов земного шара, за исключением полярных широт. Их можно встретить в тундре, лесах, альпийских лугах, степях и пустынях. 
С целью кровососания самки слепней нападают главным образом на крупных и мелких копытных, а также на человека. Укусы, наносимые слепнями, причиняют сильное беспокойство, как людям, так и животным (Калмыков, 1955). Нападение их на животных очень назойливо, укусы болезнены, вводимая в ранку слюна токсична. Наибольшее беспокоиство доставляют животным во время выпаса. При массовых нападениях слепней резко снижается продуктивность сельскохозяйственных животных (Виолович, 1968). В некоторых местах, в период массового нападения слепней, прекращают дневной выпас скота. В природе слепни нападают на диких животных: лосей, косуль, оленей, а также зайцев и мелких грызунов, что имеет очень большое эпизоотологическое значение, так как способствует передаче заболеваний различной природы. Эпидемиологическое значение слепней заключается в том, что они являются механическими переносчиками туляремии, сибирской язвы, парафимбиоза лошадей, инфекционной анемии лошадей, калабарского отека (лаоз), пастереллеза буйволов и других природноочаговых болезней (Олсуфьев, 1977). В связи с этим, слепни имеют большое сельскохозяйственное, медицинское и ветеринарное значение. Поэтому, для организации борьбы с ними требуются более глубокие и детальные исследования этого семейства.

Фауна и экология слепней Севернего Казахстана изучена недостаточно, особенно в восточной его части. Можно сказать, что фауна слепней изучена фактически лишь в некоторых районах Севернего Казахстана.

По данным исследователей на территории Казахстана обитают около 80 видов слепней. В некоторных районах, северной части Казахстана исследования проводились в 50-х годах. Крайне важно изучение современного состояния фауны слепней на территории Казахстана, особенно в северной части. Современные сведения о фауне и экологии слепней по Северному Казахстану отсутствуют.

Целью работы является установление состояния фауны и фенологической особенности слепней обитающих на территории Северной части Казахстана. Результаты исследования дадут возможность разработать эффективные меры борьбы с ними в местных условиях. Для выполнения данной цели были поставлены следующие задачи: проанализиролвать на основе собственных полевых сборов, коллекционных и литературных данных видовой состав слепней на территории. 
Практическое значение работы состоит в выявлении массовых видов слепней и получение данных об их относительтной численности и сроках нападения на животных.

Материалом для исследования послужили собственные сборы насекомых. Энтомологические исследования по сбору насекомых проводились на территории 16 животноводческих обьектах районов Акмолинской и Костанайской области. Сборы и наблюдения были проведены в хозяйствах, размещенных в разных природно-климатических условиях. Сбор проводили в основном энтомологическим сачком и с помощью пробирок с ваткой, смоченной хлороформом. Отлов насекомых осуществляли с разных видов животных. Собирали в местах их дневок кошением по траве, в животноводческих постойках. На пастбище учет численности слепней проводили методом отлова их с животных энтомологическим сачком в течение 15 минут. Изучение суточной активности нападения насекомых на животных осуществлялось в течение всего летнего сезона один раз в неделю. При изучении фенологии слепней регистрировали начало и окончание лета и активности их. Были собраны около 800 экземпляров зоологических таксонов. Местами в течение нескольких недель наблюдаются массовые нападения слепней. Массовые нападения слепней продолжаются большую часть летнего периода.

По всем семействам кровососущих двукрылых были изданы определители и справочники, обеспечивающие высокий научный уровень прикладных исследований по проблеме гнуса. Видовую принадлежность отловленных слепней устанавливали с помощью определителей Н.Г.Ольсуфева, использовались монографии В.В.Шевченко.

В целом в районе исследований были выявлены 23 видов слепней, относящиеся к 5 родам: Chrysops relictus Mg., Chrysops convarus Loew, Chrysops sepulcralis, Tabanus bovinus L., Tabanus rupium(Brauer),Tabanus sabuletorum Lw.,Tabanus bromius Zinne, Tabanus autumnalis L, Tabanus confinis Ztt, Tabanus brunneocalosus, H.ols, Atylotys agrestistis (wied), Atylotys quadrifarius Lw., Atylotys rusticus, Haematopota turkestanica Krob., Haematopota pluvialis(L.), Haematopota hispanica(Szil.), Hybomitra expolliata Pand, Hybomitra schineri Lyneb., Hybomitra acuminate Lw., Hybomitra ciureai, Hybomitra montana staigeri Lyneb, Hybomitra lurida Flln, Нybomitra peculiaris. Массовая активность нападения в июле.Доминируют: Т, sabuletorum, Т. bromius, Н. expollicata. Как показали, наши сборы и наблюдения слепни относятся к числу самых многочисленных и назойливых компонентов гнуса. В Казахстане слепни представлены 
следующими фаунистическими

группировками:

европейские,

средиземноморские, туркестанские, монгольские, центральноазиатские (Шевченко,1961). В Акмолинскойи Костанайской областях нами были обнаружены европейские, туркестанские, средиземноморские и монгольские элементы. Проявление сезонной активности слепней приходится на май -август месяцы. Первые окрыленные особи появляются на третьей декаде мая. В начале июня активно летали все виды, характерные для области. Суточная активность слепней зависит от погоды и температуры воздуха и имеет два дневных пика. Лёт самок начинается с 7 часа утра при температуре 18-200С и ярком солнечном освещении. С повышением температуры воздуха активность и нападение слепней постепенно возрастают,достигая первого пика в 11 часов дня. К 20-21 час лёт прекращается. При температуре ниже 14-150С их активность прекращается. Слепни солнце-теплолюбивы.Первое появление окрыленных слепней совпадает с наступлением теплых дней в начале мая. К ним относятся: H. muehlfeldi, H. bimaculata, T. bromius. В начале июня появляются H. montana morgani, H. expollicata, H.nitidifrons confiformis, Ch.caecutiens, Ch. suavis, Ch.relictus, в третьей декаде июня были обнаружены T. miii, T. bovinus, T. autumnalis, Ch. divaricatus, H. erberi, Haem. pluvialis, Haem. subcylindrica. сновной состав фауны включает весенне-летние и летние виды. Начало активности табанидов отмечено в третьей декаде мая (Hybomitra ciureai Seg., Hyb. nitidifrons confiformis Chv. et M., Tabanus tergestinus Egger). Большинство видов летает в июне-июле (77 и 90\% соответственно). В августе отмечен спад активности (39\%), в сентябре отловлен только ChrysopsrelictusMg. При этом численно доминировал Tabanus bovinus L, Hybomitra expolliata Pand,Hybomitra acuminate Lw,Hybomitra montana staigeri Lyneb,Hybomitra peculiaris. Малочисленные виды: Tabanus sabuletorum Lw, Atylotys quadrifarius Lw. Остальные виды отнесены к субдоминантным.Массовый лет кровососущих двухкрылых наблюдается в начале июля. Животноводческих хозяйствах были собраны слепней (Tabanidae) -800 экз.

Полученные данные о видовом составе, о сроках лёта и интенвивности нападения слепней, по сезонному и суточному ходу численности массовых видов служат экологическим обоснованием для разработки рациональных мер по снижению численности слепней. Современные программы защиты от гнуса, кроме эффективности, должны соизмерять стоимость защитных мероприятий с экономическим эффектом их применения и с экологической безопасностью для окружающей среды. В результате исследования в были определены , что фауна 
кровососущих двукрылых насекомых в хозяйствах северных областях относятся к следующим родам: Tabanidae, Chrysops, Haematopota, Hybomitra, Atylotys. Фауна и фенологические особенности слепней исследуемых хозяйствах зависит от климатических особенностей и тесно связан с содержанием животных.

\section{$* * *$}

1. Айбасов Х.А., Шакирзянова М.С. 1958. Материалы по фауне слепней Юго-Западного Алтая // Тр. Ин-та зоологии АН КазССР. Т. VIII. А-Ата: изд-во АН КазССР. С. 209-214.

2. Алиханов.Ш.А. Кровососущие двукрылые (Diptera Culicidae, Ceratopogonidae,Simullidae,Tabanidae) Каркаралинского и Баянаульского горно-лесных массивов. Автореф.канд.дисс.Алма-Ата.1989-25с.

3. Бей-Биенко Г.Я. Определитель насекомых Европейской части СССР / Г.Я. Бей-Биенко. Л.: Наука, 1969. Т. 5. Ч. 1, 2. С. 805-860.

4. Даутбаева К.А. 1973. О слепнях (Diptera, Tabanidae) поймы нижнего течения р. СырДарьи // Биология и география. Вып. 8. А-Ата. Изд-во КазГУ. С. 94-98.

5. Растегаев К.С. Материалы к изучению слепней на крупном рогатом скоте // Проблемы ветеринарной дерматологии, арахнологии и энтомологии. С. 1954. С.210-213.

6. Тусупова К.С., Шевченко В.В. 1980. О слепнях (Diptera, Tabanidae) из окрестностей города Семипалатинска // Особенности биологии и морфологии животных Казахстана. ААта. С. 37-45. 